\title{
静岡県広野海岸の海岸堤防の被災について \\ Causes of damage of seawall on Hirono coast in Shizuoka Prefecture
}

\author{
宇多高明 $*$ 大石守伸 $*$ ・板橋直樹 $* *$ 有村盾一 ${ }^{* * *}$ \\ Takaaki Uda, Morinobu Ohishi, Naoki Itabashi and Jun-ichi Arimura
}

Abstract

\begin{abstract}
Causes of damages of seawall due to storm waves on the Hirono coast in Shizuoka Prefecture were investigated. In 1997 high waves were generated by five typhoons in this area. Direct cause of the failure of the seawall is due to the wave action, but gradual decrease of sea bed due to beach erosion is the indirect cause. Beach erosion of this area is deeply connected with the retreat of river mouth bar of the Abe River.
\end{abstract}

Keywords: seawall, damage, beach erosion, topographic changes.

\section{1. まえがき}

駿河湾に面し、安倍川河口の右岸側に広がる広野海岸では、1960 年代に海岸侵食が急速に進み、海岸堤防之消 波工が連続的に設置された海岸となった。海岸侵食の原因は、安倍川で広範に行われた砂利採取によって河川流 下土仯量が減少し、沿岸漂砂量とのバランスが崩れて河ロテルタの縮小が起こったものである（野田・橋本、19 81）。現在では海岸堤防の前面には砂泜が全く存在しない人工海岸となっている。1997 年、この海岸では台風に 伴う高波浪か頻繁に来襲し、海岸堤防が崩壊するという被害が出た。ここではこの被害の実態と原因についてま とめ、対策案について検討する。侵食海岸の数が増加している現在、広野海岸を対象とした検討は、他の同様な 条件下にある海岸の保全について検討する際にも役立つと考えられるので、できる限り一般的に考察する。

\section{2. 広野海岸の過去の侵食状況之海岸保全}

広野海岸は、図- 1 に示すように急流河川である安倍川の河口右岸側に伸びる延長約 $0.7 \mathrm{~km}$ の海岸である。古 くは砂碟泜であったが、現在では海岸線の全域が海岸堤防や消波工によって守られた人工海岸となっている。こ の海岸については、野田・橋本（1981）が 1947 年撮影の空中写真を基準とした汀線変化を示しているので、それ に広野海岸の区域を加えて示すと図ー 2 となる。安倍川河口における 1976 年まで、 29 年間の汀線変化が示され ている。これによれば、広野海岸では河口テルタの後退と連動して汀線が後退したが、用宗漁港より南西側（図 -2では右側）の区域では、用宗漁港の防波堤が北向きの沿岸漂砂移動を阻止したため、汀線はあまり後退しな かったことが明らかである。このことは、広野海岸の侵食は安倍川からの流出土仯量の減少によって生じたが、 この海岸からの侵食土砂は安倍川河口を通過して静岡海岸方面へと北向きに流出したことを示している。

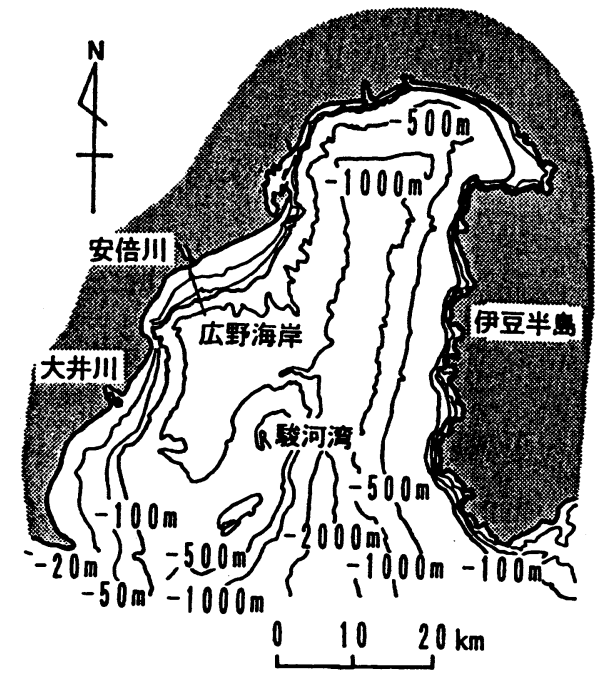

図一 1 静岡県広野海岸の位置

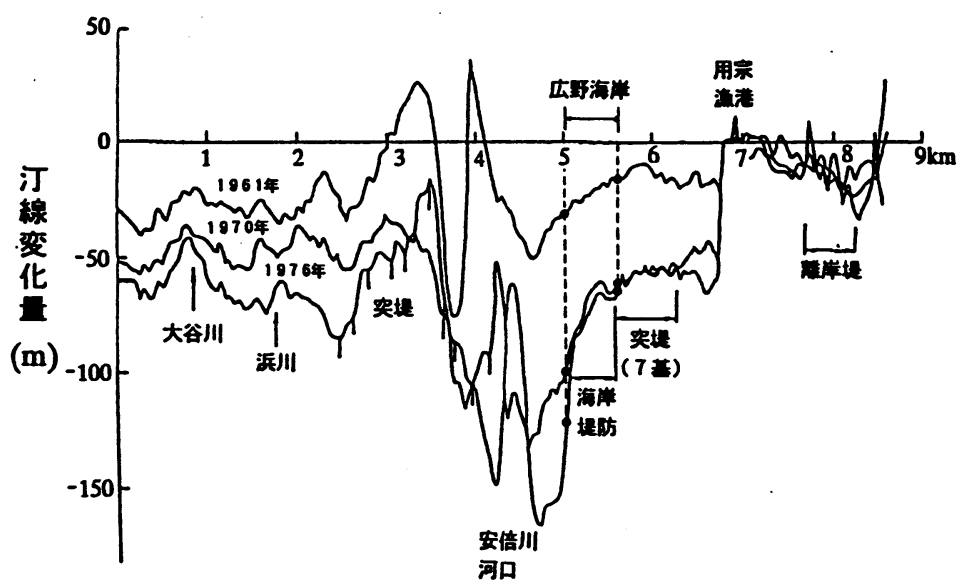

図-2 安倍川河口の汀線変化（野田・橋本、1981 より）

\begin{tabular}{|c|c|c|c|}
\hline & 正会員 工博 & $\begin{array}{l}\text { 建設省土木研究所河川部長（テ305 } \\
\text { 静岡県静岡土木事務所用宗支所 }\end{array}$ & 茨城県つくば市旭 1) \\
\hline$* *$ & 正会員 & 㑣)イ・エヌ・エー＼cjkstart海岸環境部 & \\
\hline
\end{tabular}


広野海岸における過去の海岸災害と対策の経稦は図ー 3 の ようにまとめられる。なお、図には第 5 節で述べる深浅測量 の测線配置も示す。図ー2に示したように、1960年代におけ る激しい侵食に対して、1964 年より1966 年まで延長 $614 \mathrm{~m}$ に わたって海岸堤防が建設されたあと、1969 年から 1973 年に 延長 $630 \mathrm{~m}$ の消波工が設置された。1974 年にはこれらの施設 の北端、すなわち安倍川河口砂州之の接点で侵食災害を受け たために、蛇かごが延長 $65 \mathrm{~m}$ にわたって設置された。その後 2 号離岸堤が 1974 1984 年に長い時間かけて建設されたが、 1985 年には広野海岸の南部で基礎工が $290 \mathrm{~m}$ 、護岸工が $298 \mathrm{~m}$ 、 消波工 $290 \mathrm{~m}$ が災害復旧として修復された。さらに 1986 年に は、1985 年の災害区域の北側隣接域で同様な災害復旧が行わ れた。その後 1987 年以降、3,4 号離岸堤の建設工事が進んだ が、1993 年には 1974 年当時災害を受けた場所が再度修復さ れた。このような状況で推移したのち、1997 年 9 月には No. 90 と No. 91 の間で海岸堤防が陥没するという被害が出た。以 上のように広野海岸では侵食の激化とともに、繰り返して海 岸災害復旧が行われてきた。

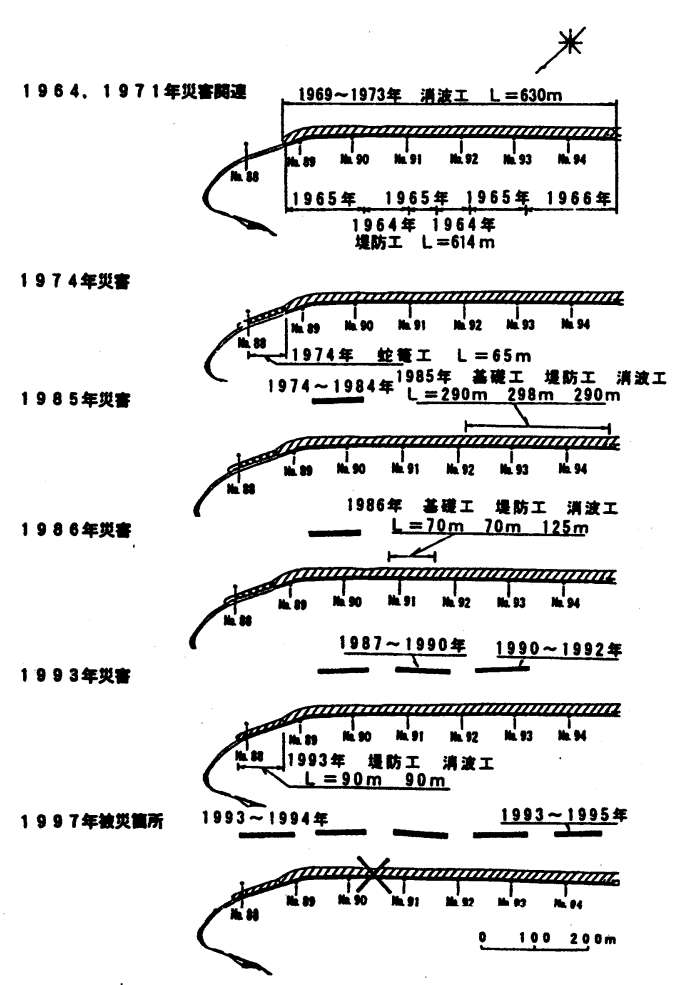

\section{3. 広野海岸の現況}

図-3 広野海岸における過去の海岸施設災害状況

写真ー 1 には静岡市の埋立地と、その北側に広がる広野海岸の全体状況を示す。写真の上部が北側である。写 真に示すように、静岡市の埋立地は旧海岸線から $80 \mathrm{~m}$ 沖に突出して造られており、護岸前面には離岸堤が連続的 に設置されている。広野海岸には海岸堤防と消波工が連続的に設置されているか、その沖には堤長 $100 \mathrm{~m}$ 、開口幅 $50 \mathrm{~m}$ の離岸堤 5 基が設置されている。広野海岸の北端は安倍川の河口砂州と接しているが、そこでの汀線はフッ ク状に後退している。これからも分かるように、広野海岸での沿岸漂砂の卓越方向は北向き、すなわち安倍川の 河口へと向かう方向である。一方、写真ー 1 に示すように、静岡市の埋立地が突出するとともに南侧には用宗漁 港の防波堤が伸びているために、南側からの沿岸漂砂の供給は断たれている。このため北向きの沿岸漂砂の均衡 が厽れ、現在も侵食が進んでいる。

写真ー 2 には、写真ー 1 の上半分に焦点を当てた空中写真を示す。広野海岸の北部と安倍川の河口仯州を示す。 手前侧には広野海岸の 1,2 号離岸堤があり、その先に見えるのが安倍川河口砂州である。この仯州は宇多・小菅 （1997）に述へらられているように、右岸堤防との接点付近で砂州高が約 $4 \mathrm{~m}$ 之最も高く、写真上方へ、すなわち北 向きに高さが減少している。河口の開口部は北端に開いており、近年ではこの位置はかなり安定している。安倍 川からは、平均的に見れば約 $13 \times 10^{4} \mathrm{~m}^{3} / \mathrm{yr}$ の砂礫が供給されているか、洪水時に砂州をフラッシュして砂州沖に 一部の土砂が堆積しても、北向きの沿岸漂砂の卓越により、流出土砂は河口の北側に広がる静岡海岸方面へ之流 出し、右岸侧への土砂供給はない。それだけではなく、河口の右岸侧の広野海岸から北向きに土砂の流出が起き ており、安倍川の河口砂州も南部ほど急深になっている。さらに、現況では河口砂州の汀線はこの地点における 卓越波の入射方向 $\left(S 14^{\circ} \mathrm{E}\right)$ 之直角方向となって安定していることが明らかにされている（宇多・小菅、1997）。

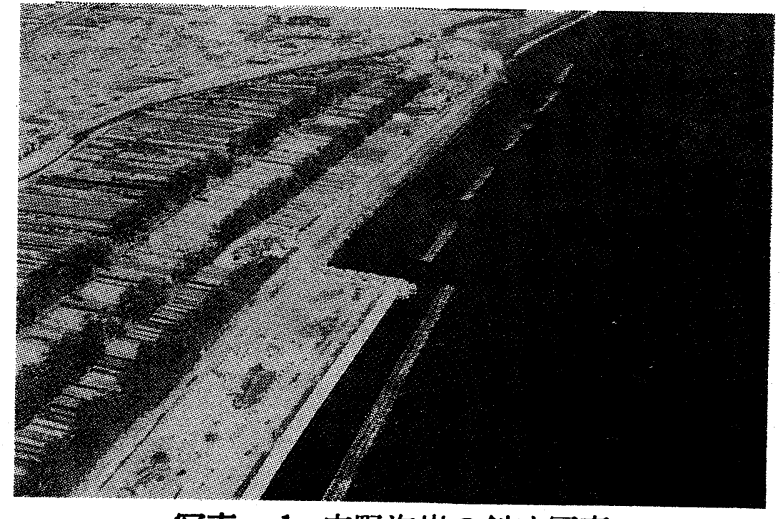

写真- 1 広野海岸の斜め写真

（1997 年 2 月 20 日撮影）

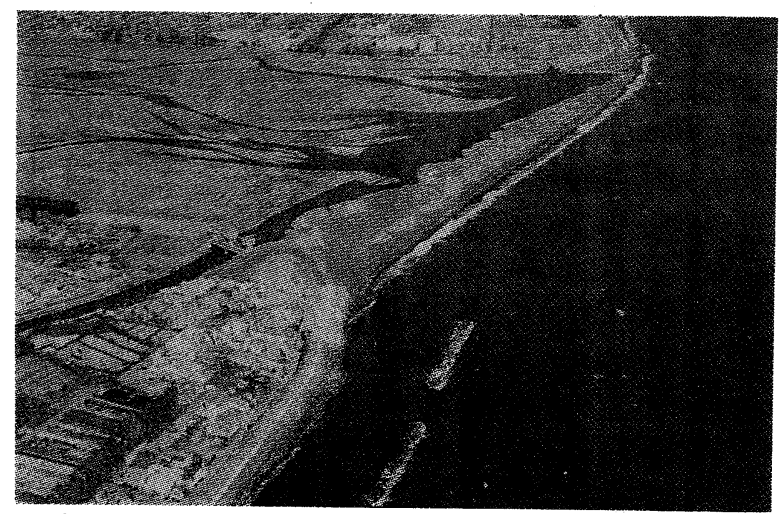

写真 -2 広野海岸に隣接する安倍川河口の斜め写真 (1997 年 2 月 20 日撮影) 


\section{1997 年の台風に伴う高波浪}

1997 年には広野海岸に強い影響を及ぼしたと考えら れる台風が 5 回来襲している。

図-4 には台風 7, 8, 9,13,18 号の進路を示す。また、 表一 1 は御前崎港における波浪観測をもとに、台風、 高波浪の起時、最大有義波高、最大波高、周期を整理 したものである。6月 20 日の 7 号台風以来、海岸堤防 の災害が起こるまでの期間に 5 回の台風による高波浪 が生じている。これらのうち有義波高が最大となった のは、 7 号台風時の $4.65 \mathrm{~m}$ であり、それに 9 号、18 号 台風による高波浪がわずかの差で続いている。

\section{5. 海岸災害筒所付近における海底地形変化}

広野海岸では経年的に深浅測量が行われてきている。 ここでは 1995 年 10 月、1996 年 2 月、1997 年 8 月、 9 月测量の深浅図をもとに広野海岸の海底地形変化につ いて検討してみる。図一5にはこれらの時期の深浅図 を示す。深浅図のうち、1997 年 8 月の測量のみは災害 調査を目的としたために、測量範囲が他の場合と比較 して狭い。現在、広野海岸は北端に No. 88 が位置し、 南端の埋立地との境界は No. 95 にあるが、図ー5 では 経年的に拡大されてきた静岡市の埋立地の形状変化も 示している。さらに、図ー5では、-6〜-7m の範囲之、 -6〜-5m の範囲をそれぞれハッチで示し、これらの区域 の時間的広がりについても記入してある。

1995 年では静岡市の埋立地が長さ $150 \mathrm{~m}$ 北側に延長 された。この場合、埋立地の沖侧を区切る護岸部分が

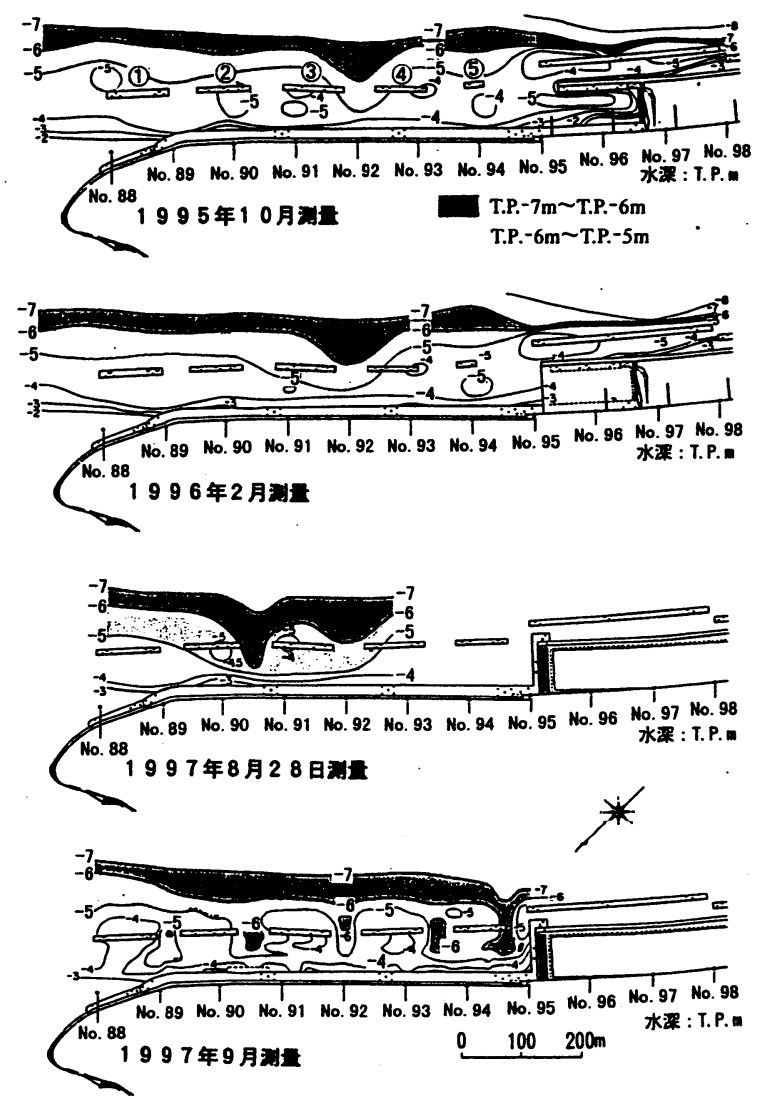

図- 5 広野海岸の深浅図

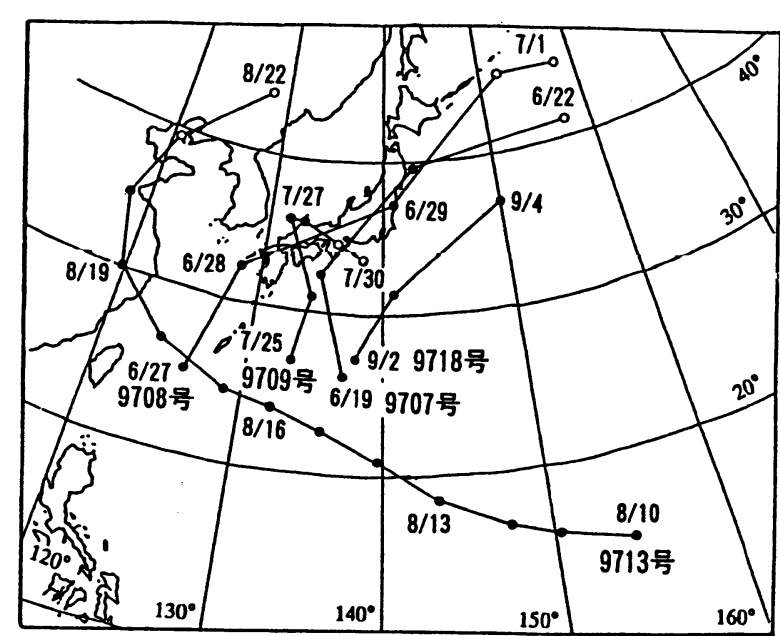

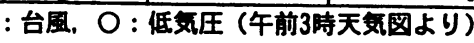

龱－41997 年に日本に来襲した台風の進路

表- 1 御前崎港における台風来襲時の波高記録

\begin{tabular}{|c|c|c|c|}
\hline 台風 & 旦時 & 㿞大有義波高 (m) & 有義波周期（s） \\
\hline 9707 & $\begin{array}{l}\text { 6月20日 } \\
13: 50\end{array}$ & $\begin{array}{l}4.65 \\
(7.29)\end{array}$ & $\begin{array}{c}14.1 \\
(12.8)\end{array}$ \\
\hline 9708 & $\begin{array}{c}\text { 6月29日 } \\
3: 50\end{array}$ & $\begin{array}{c}2.53 \\
(4.47)\end{array}$ & $\left.\begin{array}{lll}1 & 1 & 1 \\
(1 & 1 & 1 \\
1\end{array}\right)$ \\
\hline 9709 & $\begin{array}{l}\text { 7月26日 } \\
13: 50\end{array}$ & 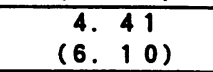 & $\left.\begin{array}{lll}1 & 3.4 & 4 \\
(1 & 5 . & 5\end{array}\right)$ \\
\hline 9713 & $\begin{array}{c}8 \text { 815日 } \\
7: 50 \\
\end{array}$ & $\begin{array}{r}3.37 \\
(5.32)\end{array}$ & $\begin{array}{l}12.5 \\
(12.8)\end{array}$ \\
\hline 9718 & $\begin{array}{l}\text { 9月3日 } \\
7: 50\end{array}$ & $\begin{array}{r}4.29 \\
(5.443)\end{array}$ & $\begin{array}{l}13.5 \\
(13.8)\end{array}$ \\
\hline
\end{tabular}

（）は浱大波

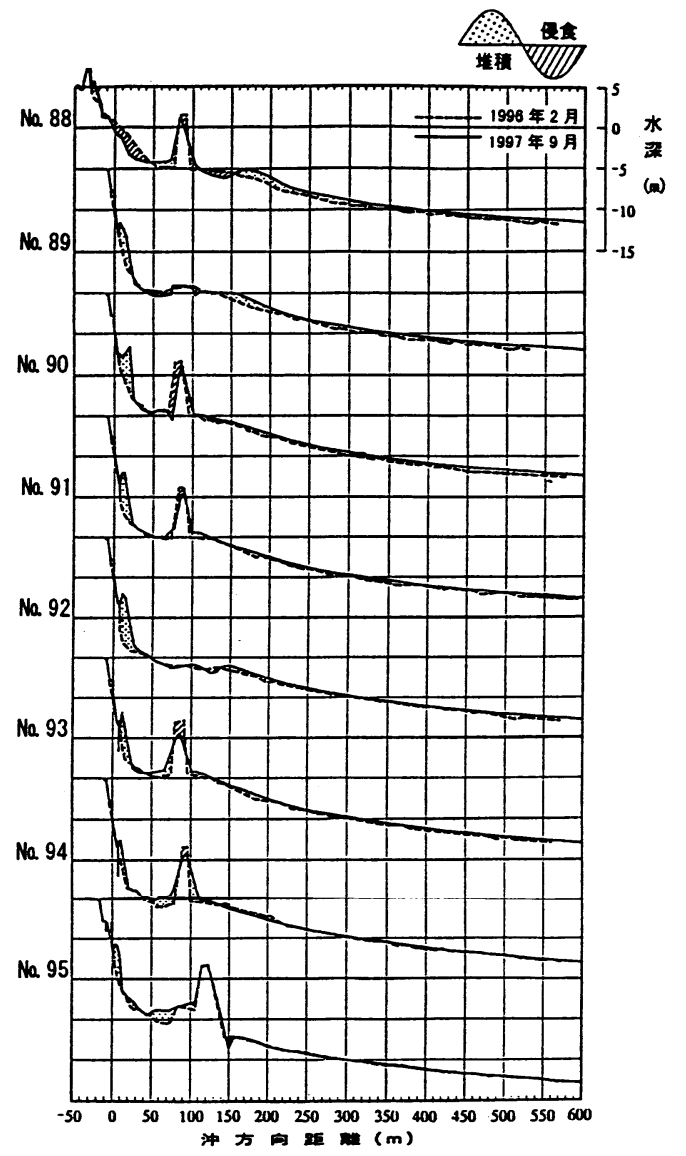

図-6 広野海岸における海泜繸断形の比較 
離岸堤状に建設されたため、その岸側には土砂が堆積して浅くなっている。広野海岸には 5 基の離岸堤が設置さ れていたが、3 号と 4 号堤の間の開口部では-6〜-5m の範囲が岸向きに入り込んでいる。これを除けば、そのほか の離岸堤の沖合では等深線はほぼ平行に伸びている。1996 年 2 月では、1995 年 7 月段階で 3,4 号離岸堤の間でや や凶状となっていた $-5 m$ の等深線が 3 号堤を包含する範囲まで岸側に接近し、全体に深くなったことが分かる。

1997 年 8 月 28 日では、 No. 90 と No. 91 の間で著しい深みが舌状に岸に接近し、海岸堤防の前面が非常に深くな った。この段階で No. 90 と No. 91 の間では海岸堤防が吸い出しを受けて陥没し、表のり面が崩壊した。

1997 年 9 月では、全体にそれ以前と比較して離岸堤の開口部を中心として㳭くなったことが分かる。離岸堤の 開口部にはいずれも梁みがあるか、全体的に南部に位置する離岸堤ほど開口部の深みの範同が広く、かつ離岸堤 の岸侧深く深みが迫っている。また同時に、-6m および-7m の等深線は離岸堤群から北向きに次第に離岸距離が大 きくなっている。これはすでに宇多・小菅（1997）が指摘したように、安倍川の河口仯州に近づくと次第に水深 が小さくなること、そして不透過性の構造物である、埋立地の護岸との境界付近で潹掘れが最も著しく、北側に 次第に浅くなる点は、この地区で北向きの沿岸漂砂が卓越しており、護岸で漂砂が遮られた場所で侵食が著しい ことを意味している。

図一6には、広野海岸における 1996 年 2 月と 1997 年 9 月の深浅測量に基つくく海泜縦断形の変化を示す。いず れの断面でも陸上部から急勾配で $-5 \mathrm{~m}$ 程度まで落ち込み、そのあとは比較的なだらかな海底形状を有している。 いずれの離岸堤も設置水深は約 $5 \mathrm{~m}$ であるが、消波ブロックの沈下・散乱によって、離岸堤の天端高は当初の T.P .$+1.8 \mathrm{~m}$ よりもかなり低下している。

\section{6. 現地写真による海岸讙岸の被苂状況の分析}

去野海岸では 1997 年の 6 月以降、台風 7 号などの高波浪がたびたび来襲し、激しい越波が生じた。以下ではま ず、高波浪時の海岸状況を現地写真により調べてみる。写真-3は、6月 20 日の台風 7 号時の高波浪の越波状況 である。No. 95 のすぐ南側に位置する静岡市の埋立護岸上から北側の海岸堤防上への越波状況を撮影したもので ある。写真左端には観测者が立っているがここでの堤防天端高は T. P. +10mである。また、波返し工の天端高が T. P. +7. 26m であったことを考慮すれば、海岸堤防上 7 8m まで砝波のしぶきが上がっていることが分かる。写真 -4 4、8月 18 日に No. $91+60 \mathrm{~m}$ 付近で撮影した海岸堤防の旧天端の陥没状況であって、海岸堤防内に大きな空洞 が生じていることが分かる。写真-5 は、8 月 25 日撮影の海岸堤防ののり面の被災状況である。パラペットと旧 堤ののり面は前落せずに済んでいるが、その裏側の状況を観察すると、裏込め土砂がのり面に沿って滑り落ちた ことがのり面 (土羽) の縞模様から判読される。

写真- 6 は、No. 93 地点の護岸への越波状況を 1997 年 9 月 3 日に撮影したものである。海岸堤防から左侧では 全域が砕波の白濁域に入っている。また白波が海岸堤防上の旧天端に打ち上がっていることが見てとれる。さら に同じく 9 月 3 日撮影の写真一 7 は、旧堤のパラペットを乗り越えて越波が起きている状況であり、パラペット の背後に大量の海水が入り込んでいる。この海水は、堤体ののり面下を通る戻り流れを生じ、その結果写真 -8 に示すように堤防はパラペット部分を残すのみで、その下部が大きな空洞ができるほどに破壊された。写真一 9 は9月 3 日の斜め写真である。延長 $65 \mathrm{~m}$ にわたって海岸堤防が被災している。

以上に述へた海岸堤防の被災状況を観察すると、1997 年にはたびたび高波浪が来襲したことも寄与して、海岸 堤防の堤体内で空洞化が進んだ可能性が高いと判断される。そこで、1997 年10月9 日に空洞化調査を実施した。

写真- 10 は、No. 92 付近における海岸堤防の堤体内の空洞状況である。のり面の基礎である硶が宙に浮いて おり、空洞の高さは約 $1.1 \mathrm{~m}$ である。同様に写真-11 1 は、No. 93 付近の空洞状沉である。これらの調查から、広 野海岸の海岸堤防では空洞化がかなり進んできており、このことが海岸堤防の大きな破壊要因之考えられる。

\section{7. 対策案の検討}

図ー5に示したように、広野海岸では時間経過とともに侵食が進んできたことが注目される。すなわち、単に 局所的な洗掘によって海岸堤防が被災したのみであれば、堤防を復旧するとともに洗掘防止のために消波工を設 置すればよいが、時間経過とともに次第に激化する方向で侵食が進んできている場合には、被災筫所を復旧する のみでは、その周辺区域（とくに北側隣接区域）で再び海岸堤防が被災することになる。しかも、空洞化調査に よれば、海岸堤防の表のり面の下部には広い範囲で空洞化が進んでいる。したがって海岸堤防の基礎の洗掘が進 んだ状況下において、高波浪に伴う波力が海岸堤防の表のり面に作用すれば、基礎の支持力の発揮が期待できな いため、これらの重力構造物は容易に破壊されると考えられる。また、図一 5 に示した侵食傾向は、図一 2 に示 した過去の汀線変化と調和的であって、海岸侵食がその後も継続していることをよく表している。 


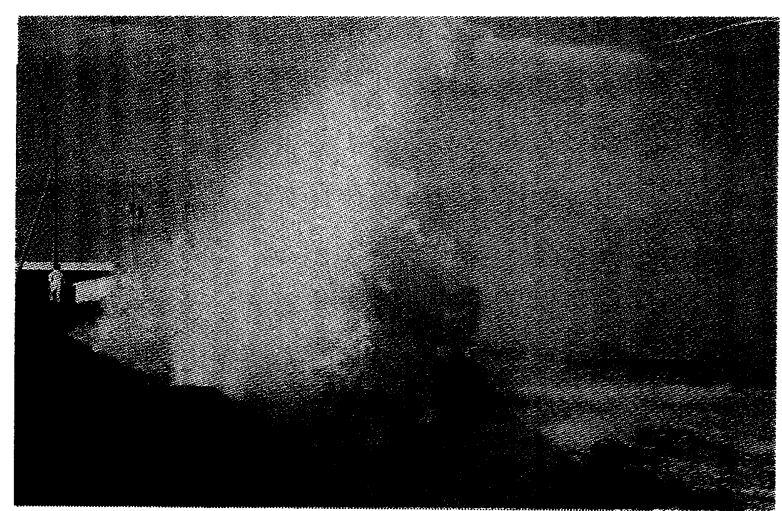

写真－ 3 No. 95 のすぐ南側に位置する静岡市の埋立護岸上 から北倒の護岸の越波状況（1997 年 6 月 20 日撮影）

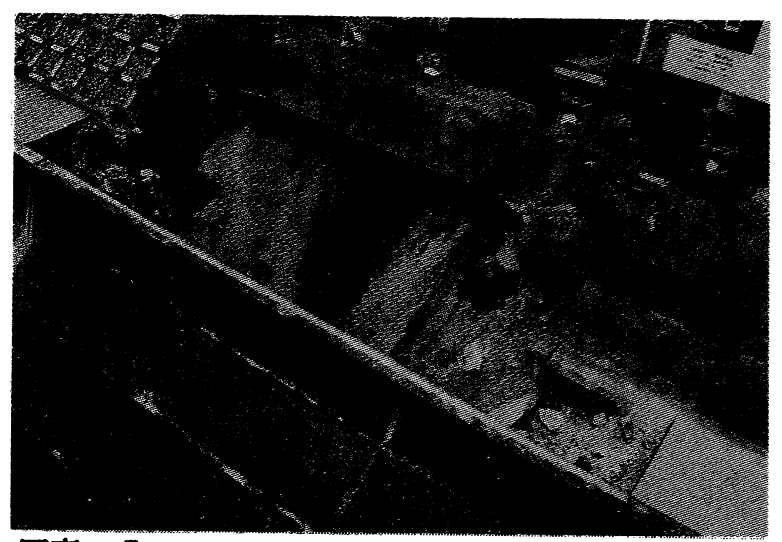

写真- 5 写真 -4 と同一地点における海岸堤防の被災状況 (1997 年 8 月 25 日撮影)

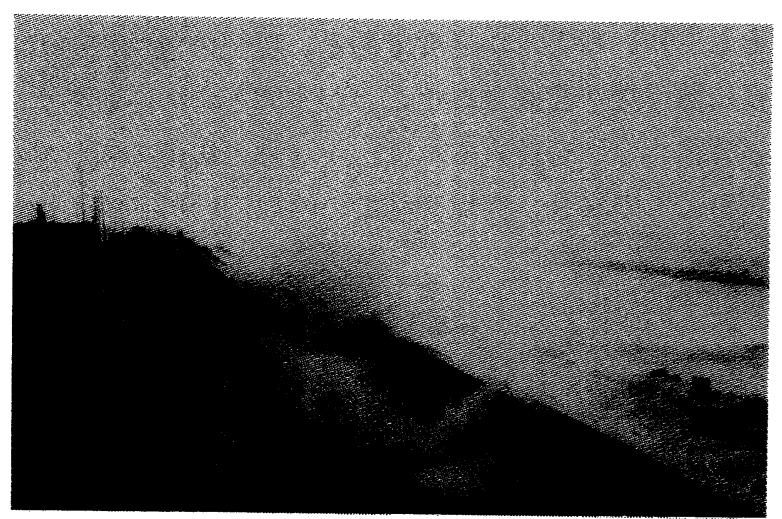

写真－7 No. 93 地点の海岸堤防への越波状況 (1997 年 9 月 3 日撮影)

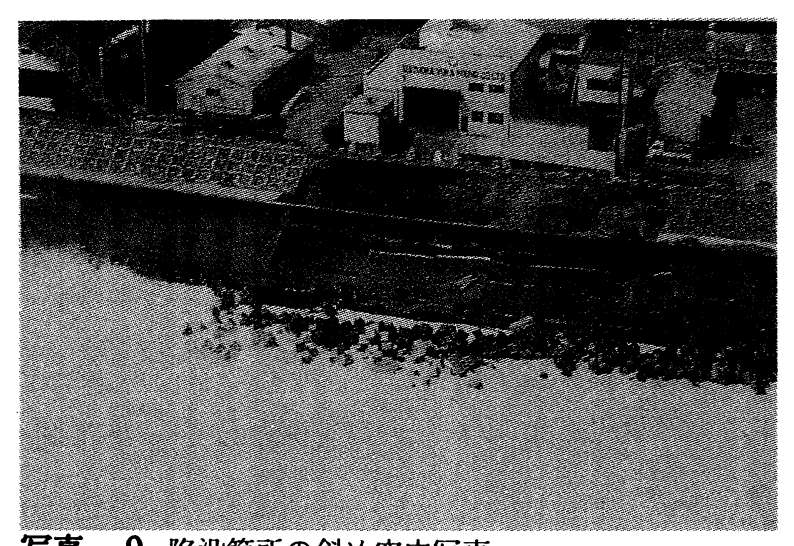

写真 -9 陥没筒所の斜め空中写真

(1997 年 9 月 3 日撮影)

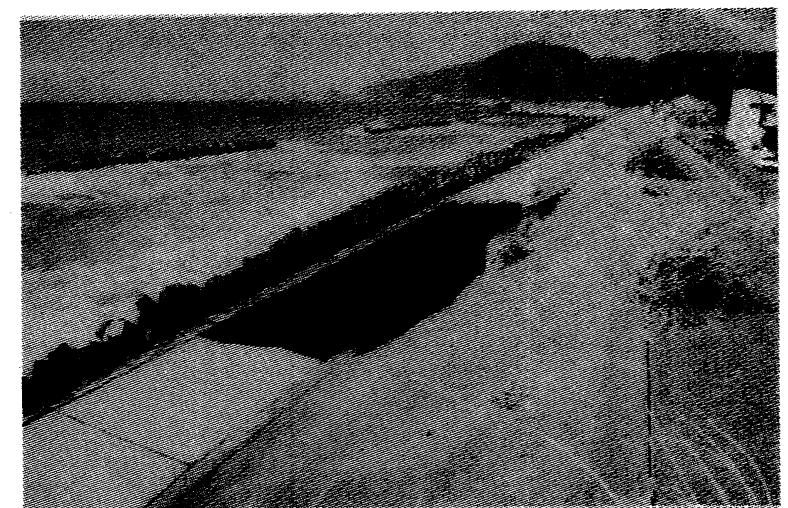

写真-4 №. $91+60 \mathrm{~m}$ 付近の離岸堤開口部での海岸堤防の のり覆工の宿没（1997 年 8 月 18 日掫影）

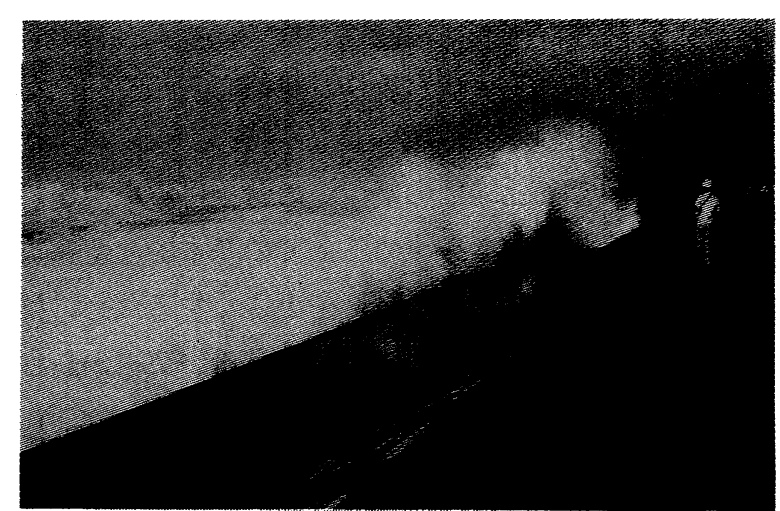

写真-6 №. 90, 91 地点の離岸堤開口部への越波状況 (1997 年 9 月 3 日撮影)

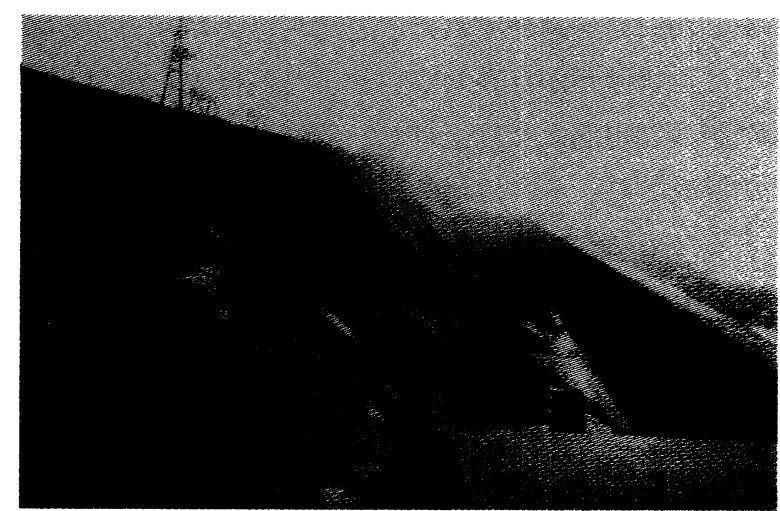

写真-8 写真-7 と同一地点における海岸堤防の前塤状況 (1997 年 9 月 3 日撮影)

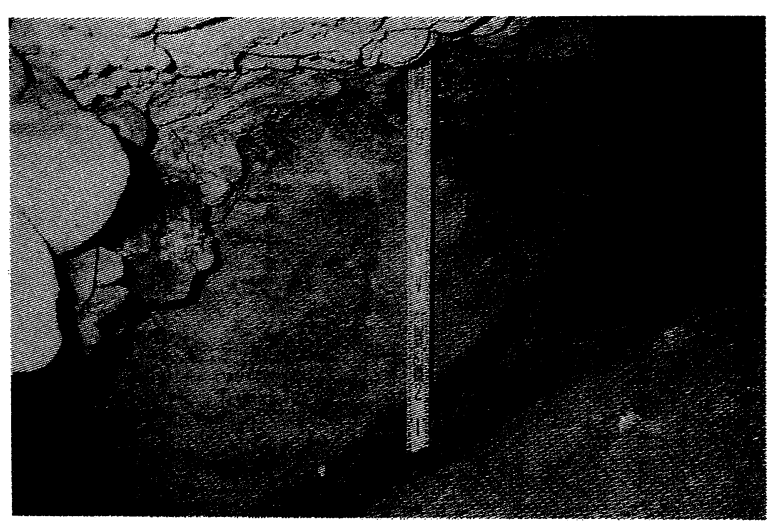

写真 -10 海岸堤防ののり面下にできた空洞 (№. 92 付近、1997 年 10 月 9 日撮影) 


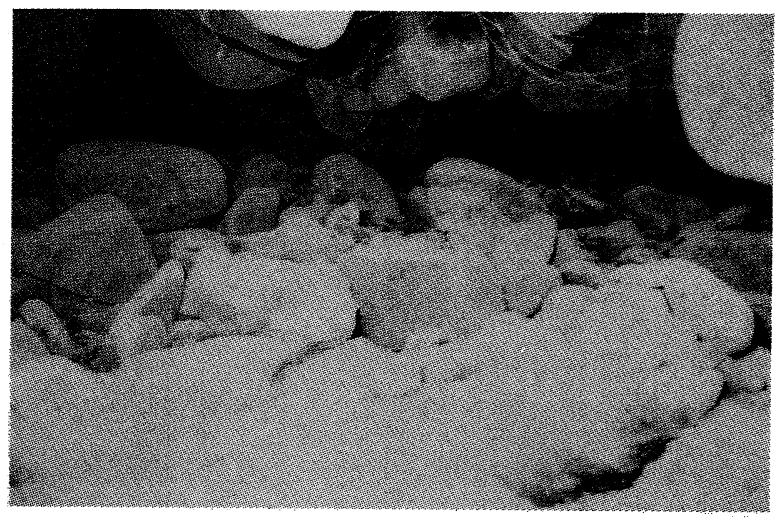

写真ー 11 海岸堤防ののり面下にできた空洞

(№. 93 付近、1997 年 10 月 9 日撮影)
以上の点を考虑すると、単に海岸堤防を復旧し消波 工を設置するのみでは数年後再び災害が繰り返され る恐れが強いと考えられる。対策案はいくつか考えら れる。まず、現在は開口部を有する離岸堤を連続堤に して開口部を塞ぐという案である。この案は開口部背 後の海岸堤防が集中的に被災するという状況を改善 する上では役立つ。しかし、この海岸での波による地 形変化の限界水深は約 7m にある（宇多、1997）のに 対し、図ー6に示したように離岸堤の沖端水深は粎 5 $\mathrm{m}$ 之浅いから、連続離岸堤の沖合の地盤高が次第に低 下し、現在でも起きている離岸堤の沈下・散乱が激化 すると推定される。このことから、この案の採用は難 しい。しかし、海岸堤防の復旧と消波工のみでは開口

部の水深が大きすぎるために、越波に対して完全な防護を図れないことも事実である。このような状況を考虑す ると、離岸堤の岸側区域で盖浜を行い、水深を小さくすることが望まれる。その場合、盖浜土砂は北向きに必ず 流出するので、北端部の離岸堤の背後に哭堤を建設した上で盖浜を行うことが望ましい。

突堤の位置と長さを決める上での基本的な留意点としては、次の点が指摘できる。まず、笑堤が下手側の河川 管理区域の砂州へ及ぼす影響を小さくするためには、第 1 号離岸堤背後中央で離岸堤の消波効果が期待できる位 置に突堤を設置することが必要である。突堤の長さについては、深浅図（図一5）を参考にして決定できる。ま ず、2 号離岸堤付近から河口方向へと海岸堤防の法線はなだらかに後退しており、相対的に離岸距離が長くなっ ている。そこで、3 号堤より南西側の海岸堤防前面の急斜面ののり尻水深 $(-4 \mathrm{~m})$ に相当する等深線をなだらかに 包絡する直線を引いたとき、この急斜面を保持することが海岸堤防の安定化に役立つと考えられることから、現 沉の海岸堤防からこの線までの長さとすることが必要である。

養泜材料としては、この海岸への土砂の供給源である安倍川の河床材料の中央粒径が 50 ～ $60 \mathrm{~mm}$ であること (宇 多、1997）を考慮すれば、この程度の粒径の磷を盖浜材量として用いることが必要である。現況の離岸堤の背後 には舌状砂州が存在しないが、れは著しい侵食が起きた後に離岸堤が設置されたことが主因と考えられる。し たがって現況より嵩上げし、消波効果が高められた離岸堤の背後へ土砂を投入すれば、かなりの規模の舌状砂州 が形成され、それは消波工の安定性確保に役立つと考えられる。この場合、突堤背後での沿岸漂砂の通過を防止 するために、突堤は必ず海岸堤防と接続しなければならない。

以上より、具体的な対策案としては、海岸堤防の復旧と消波工の設置とともに、磞を用いた養浜が有効と考え られる。なお、現在この区域に設置されている離岸堤は、天端高が T.P. $+1.8 \mathrm{~m}$ と設計されているが、沖合部が梁 くなっており、入射波浪のエネルギーが高まっていると考えられるので、天端高は安倍川河口の北側の静岡海岸 の值 (T. P. +3. 0m) と合わせることが望ましい。

\section{8. まとめ}

静岡県の安倍川河口右岸に広がる広野海岸では、過去に著しい汀線の後退が発生した。激しい侵食に対して各 種海岸保全施設の建設が進んだが、その後の海岸施設の災害状況を見ると、過去に激しい侵食を生じさせた状沉 は海岸保全施設の建設後も確実に続いていることが判明した。このことは、災害復旧にあたってその根本原因を 忠夹に考察し、それへの対処をきちんと行うべきこをを示している。なお、本研究では、具体的な対策案として 海岸堤防の復旧と消波工の設置とともに、磁を用いた養浜を提案した。今後それらの具体案の詳細について十分 な検討を行う必要がある。

\section{参考文 献}

野田英明・橋本 宏 (1981)：漂仯と海岸保全施設、技報堂出版、p. 157.

宇多高明・小菅 晋（1997）：非対称河口砂州の形成に関する実態論的研究-安倍川河口を例として一、海洋開発 論文集、Vol. 13, pp. 639-644.

宇多高明（1997）：日本の海岸侵食、山海堂、p. 442. 